九州大学学術情報リポジトリ

Kyushu University Institutional Repository

\title{
Land Degradation in Nepal: A Review on its Status and Consequences
}

\section{Paudel, Prem Prasad}

Department of Soil Conservation and Watershed Management, Nepal

Devkota, Brimala Devi

Department of Roads, Nepal

Kubota, Tetsuya

Laboratory of Erosion Control, Division of Forest Environment and Management Sciences,

Department of Forest and Forest Products Science, Faculty of Agriculture, Kyushu University

https://doi.org/10.5109/16134

出版情報: 九州大学大学院農学研究院紀要. 54 (2)，pp.477-479，2009-10-29. Faculty of Agriculture, Kyushu University

バージョン：

権利関係 : 


\title{
Land Degradation in Nepal: A Review on its Status and Consequences \\ Prem Prasad PAUDEL ${ }^{1}$, Bimala Devi DEVKOTA ${ }^{2}$ and Tetsuya KUBOTA ${ }^{3}$
}

\author{
Laboratory of Erosion Control, Division of Forest Environment and Management Sciences, \\ Department of Forest and Forest Products Science, Faculty of Agriculture, \\ Kyushu University, Fukuoka 812-8581, Japan \\ (Received June 11, 2009 and accepted July 13, 2009)
}

\begin{abstract}
The Nepal Himalaya constitute a threatened ecosystem and cultivation of marginal lands, livestock grazing and depletion of biomass cover, which are directly accelerating land degradation problems. About one third of the total area has no or little vegetation growth exhibiting the characteristics of cold desert. About 10,000 ha in Dolpa and Mustang districts (highlands areas in western Nepal) feature a process of desertification. Two-third of the country is geologically fragile where both man-land ratio and soil erosion are exceedingly high. Topsoil loss was high of 87 tons/ha/yr in sloping terrace. The problem of land degradation is causing decrease in soil quality, soil productivity are in increasing trends. Problem of malnutrition, out migration, biodiversity loss and other associated consequences are becoming major challenges. In these context, this paper highlights and presents some of the land degradation information and some efforts to deal with the facing problems.
\end{abstract}

\section{INTRODUCTION}

The problem of land degradation is becoming serious problem in Nepal. Nevertheless, an increasing awareness of the continuing deterioration of the natural resources and in reduced crop production trends over the last few decades have drawn the attention of concerned institutions. Land degradation is defined by many ways, however it is mainly related with decline (either temporarily or permanently) in soil quality, soil productivity through adverse changes in nutrient status and soil organic matter, soil structural attributes and concentration. Food and Agricultural Organization (FAO) has defined as "a process, which lowers the current and or/the potential capability of soil to produce (quantitatively and/or qualitatively) goods or services". From this definition, it implies a decline in soil productivity, deterioration in vegetative cover, qualitative and quantitative decline of water resources, degradation of soils, pollution etc as shown in Figure 1.

Land degradation in the sloping terrace through soil

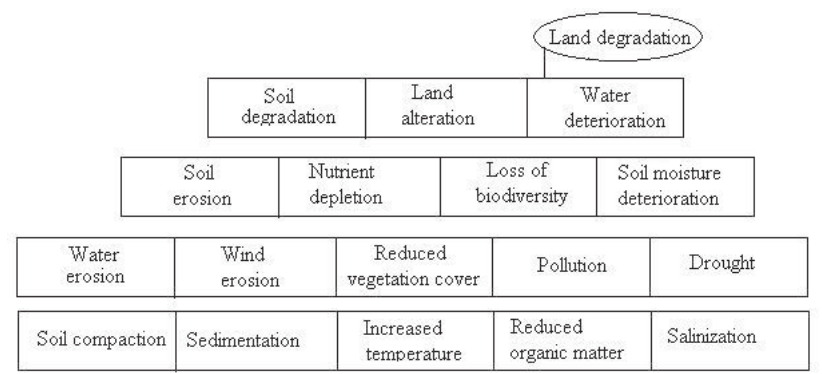

Fig. 1. Land degradation wall.

\footnotetext{
1 Department of Soil Conservation and Watershed Management, Nepal

2 Department of Roads, Nepal

${ }^{3}$ Department of Forest and Forest Products Science, Faculty of

* Agriculture, Kyushu University (Corresponding author: Kubota T., E-mail: kubot@agr.kyushu-u.ac.jp)
}

erosion is becoming one of the important factors. Maskey and Joshi (1991) have reported that soil loss was high ( 87 tons/ha/yr) in sloping terrace. This data indicates that there is tremendous amount of fertile topsoil loss from the hilly areas of Nepal. As a result onsite and offsite effects are becoming problems for the rural communities. In this context, in this paper an attempt is done to assess a) general state and problems of soil degradation, b) efforts undertaken to mitigate the problems.

\section{STUDY AREA AND METHODOLOGY}

The geological settings, topographic nature, population distribution, land use pattern are different across the different physiographic parts (High Himal, Mid hill mountain and flat Terai) of Nepal. Owing to these variations causative factors, degree of degradation and types of problems responsible for land degradation varies across the country. In high Himal Glaciers, in mid hill mountain surface erosion/landslides and in Terai flood and high rate of deforestation are becoming major dominant causative factors. Hence, in this study some prominent sites representing from different ecological regions are studied to highlight the problems. Direct field observation and published literatures are used to understand the problems and status.

\section{FINDINGS}

\section{Degradation due to surface soil erosion}

Small and long gully formation were seen and the onsite and off site effects were observed as shown in below Fig. 2.

\section{DISCUSSION}

In Nepal, overgrazing, inappropriate land use, cultivation in marginal slopes, steep terrain nature have favored for excessive soil loss (about 240 million $\mathrm{m}^{3}$ /year). 


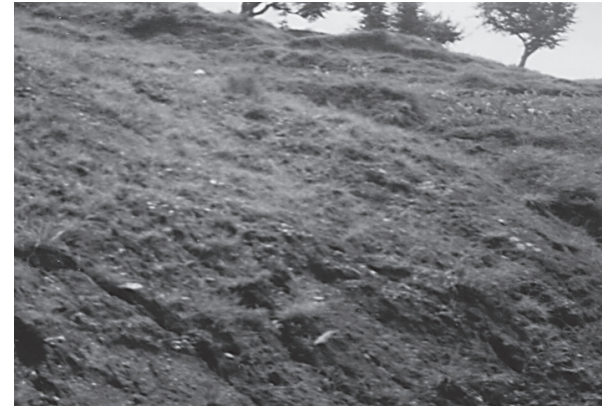

a) Gully formation with vegetation loss

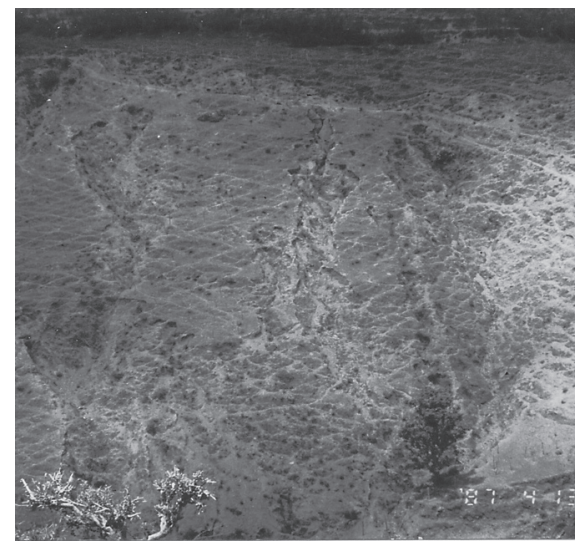

c) Intensive soil, vegetation loss

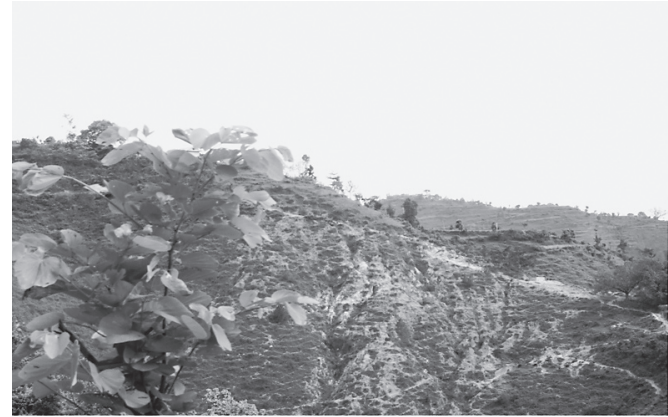

b) Hard compact soil, gully and barren surface

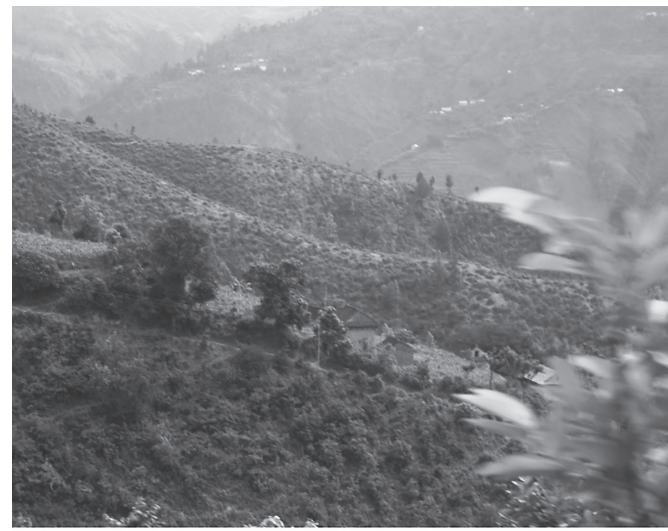

d) Vegetation loss, compact soil

Fig. 2. Different views of land degradation.

Different countermeasures like uses of bioengineering techniques are applying to minimize the problems as shown in Fig. 3.

The Nepal Himalaya constitute a threatened ecosystem and cultivation of marginal lands, livestock grazing and loss of depletion of biomass cover, which are directly accelerating land degradation problems. About one third of the total area has no or little vegetation growth (CBS, 1997) exhibiting the characteristics of cold desert. About 10,000 ha in Dolpa and Mustang districts (highlands areas in western Nepal) feature a process of desertification (HMG, 1986). Two-third of the country is geologically fragile where both man-land ratio and soil erosion are exceedingly high. It is estimated that for subsistence living, a family requires more than one hectare of land in Mountain and about 0.5 ha in the Hills and Terai depending on the land terrain and land productivity. About half of the population has not more than 0.5 ha of landholding (CBS, 1994). It is also estimated that one-third of the 75 districts of Nepal has marginal and poor to very poor watershed conditions, 13 districts having marginal watersheds, and remaining 12 districts with poor to very poor watersheds (Shrestha, 1983). Sedimentation and rise in riverbed is estimated at $10-30 \mathrm{~cm} /$ year in the Terai largely for the precipitation distribution and its wide variations in different ecological and land systems (Sthapit, 1989). Present level of information revealed that land degradation in Nepal is widespread and is mainly attributed due to soil erosion, landslides, and floods. The process of land degradation has upstream-downstream linkage. Because, the degradation in the uplands not only affects the people in its origin, but also has adverse impacts upon the lowlands. As a result, mass poverty, migration starvation, disease and civil conflicts threatening peace and security.

\section{CONCLUSION}

The review presented in this paper indicates that land degradation problem in Nepal is widespread. Two categories of soil degradation processes are recognized viz. displacement of soil material due to water/wind erosion and in situ soil deterioration. Still detail information on spatial inventory on land degradation and its consequences are seldom available. In order to deal with the facing problems, integrated approach addressing the physical, biological and socio-economic aspects of the processes of land degradation should be implemented. In addition community participation, utilization of local knowledge of people and cooperation among inter disciplinary agencies are suggested for effective management.

\section{REFERENCES}

CBS (Central bureau of statistics) 1997 Statistical year book of Nepal, Kathmandu

CBS (Central bureau of statistics) 1994 National sample census of agriculture Nepal,1991/92, highlights Kathmandu

His Majesty's Government of Nepal (HMG) 1986 Seventh Five year plan, National planning commission secretariat 


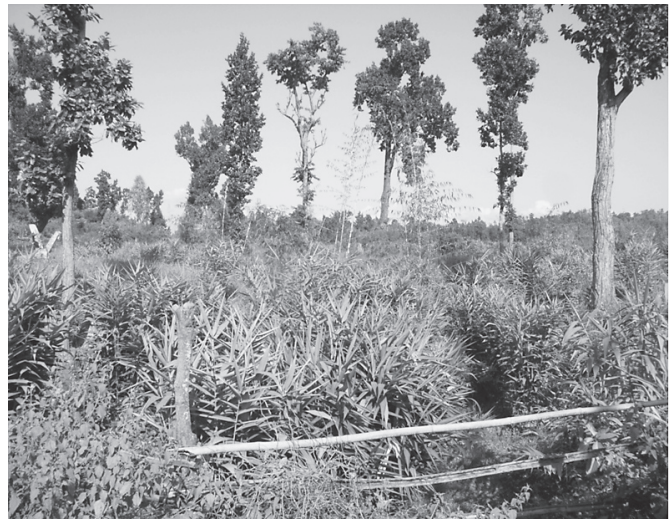

Grass plantation in open forest space

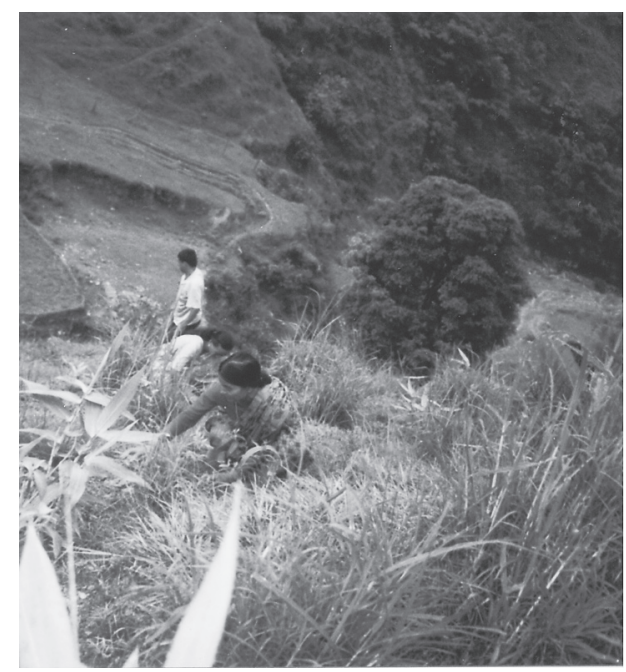

Plantation involving local people

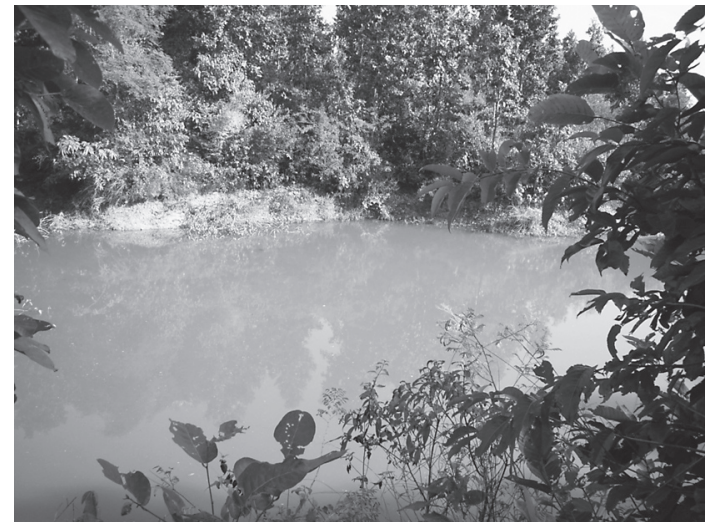

Conservation pond

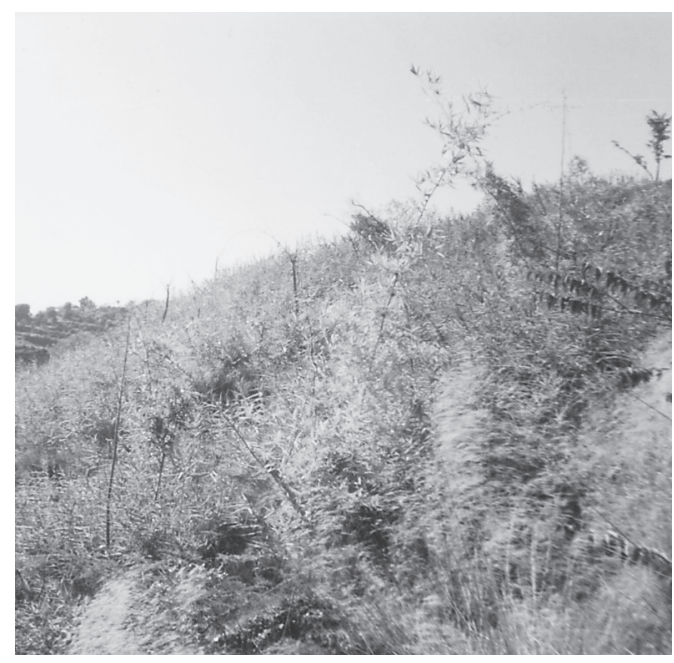

Bio engineering application

Fig. 3. Application of different techniques to mitigate the land degradation problem.

Maskey, R. B and D. Joshi 1991 Adaptive soil research on management of sloping land for sustainable agriculture in Nepal. A country report presented at the third meeting of IBSRAM, Indonesia, November 23-38

Shrestha, B. D. 1983 Watershed conditions of the districts of
Nepal, Kathmandu, HMG/UNDP/FAO

Sthapit, K. M. 1989 Land degradation and its control in Nepal. Paper presented in second regional consultative network of research and training center, September 27-29, India 